\title{
The Effect of Celebrity Endorsement on Brazilian Consumer Behavior: Does it Really Matter?
}

\author{
Ricardo Boeing ${ }^{1} \&$ Caroline Schurhaus ${ }^{2}$ \\ ${ }^{1}$ Business Administration Graduate Program, Itajaí Valley University, Brazil \\ ${ }^{2}$ Bachelor Degree in Business Administration, Itajaí Valley University, Brazil \\ Correspondence: Ricardo Boeing, Business Administration Graduate Program, João Coan St., 400, Room 408, \\ Block 1-Biguaçu, SC-ZIP 88160-000, Brazil. Tel: 55-048-3279-9552. E-mail: boeing @ univali.br
}

Received: February 19, 2014

Accepted: March 15, 2014

Online Published: April 24, 2014

doi: 10.5539/ibr.v7n5p49

URL: http://dx.doi.org/10.5539/ibr.v7n5p49

\begin{abstract}
Currently in Brazil, Firms have increasingly used celebrities as endorsers in their advertising campaigns. This exploratory and quantitative research aimed to assess the impact of celebrity endorsement in consumers' purchasing decisions. The data was compiled through a structured questionnaire administered by accessibility. Primarily, it was asked personal questions and then issues that addressed the topic, by using the Likert scale. Three statistical filters were created to analyze the answers without considering the consumers' profile, and then, they were presented comparing the average profile and different respondents' profiles. The results show that celebrity endorsement has an influence in consumers' purchasing decisions.
\end{abstract}

Keywords: celebrity endorsement, consumer behavior, purchasing decisions

\section{Introduction}

Celebrity endorsement consists of using celebrities with attractive qualities to promote products or services, and marketing professionals have been using the technique with success in their campaigns. Erdogan, Baker and Tagg (2001) and also Andrade et al. (2006), argue that the widespread use of celebrities in publicity campaigns is because they increase impact and offer the chance for those advertising to establish empathy with their public, in addition to increasing the likelihood of achieving returns in terms of Publicity and Public Relations.

Products associated with celebrities appear to have a greater impact on consumers than products that have never previously been associated with a celebrity. However, using testimonials by famous people simply because of the power the technique offers, without concerning oneself with the appropriateness of the message leads to a loss of credibility by breaking contact with reality (Leschnikowski, Schweizer, \& Drengner, 2006).

The personality chosen to make the endorsement must have specific characteristics, which will vary depending on the company's business sector and, in addition to these, must actually consume the product they advertise because otherwise the celebrity's seal of approval will end up selling the product, but will not contribute to building brand identity due to a lack of consistency. Therefore, successful campaigns are the result of correctly matching the celebrity and the message to the brand, because, when both celebrity and brand have values and followers in common, the benefits are multiplied, both for the brand and the celebrity (Milward Brown Brasil, 2006; Guimarães, 2006; Leschnikowski, Schweizer, \& Drengner, 2006).

Taking into account the relevance of this marketing tool, the objective of this study is to investigate the influence exerted by celebrities endorsement in advertisements on consumers' purchasing decisions.

\section{Literature Review}

Competition for consumers' attention and preferences demands good performance from the publicity industry, which is constantly seeking the most effective form of communication (Walker, Langmeyer, \& Langmeyer, 1992). Publicity campaigns stand out from the other techniques on the endless list of strategies proposed by marketing because they present an organization to society, providing necessary information about the fact that it exists, the image it conveys to its consumers, the products and/or services its supplies and the benefits that might be expected from using them, with the objective of influencing the market to give preference to a given organization to provide for its wants and requirements and to influence its value in the market (Mccarthy \& 
Perreaut, 1997; Matos \& Veiga, 2002; Dornelas, 2007).

The theme proposed in this study has been the focus of numerous studies around the world (Mccracken, 1989; Erdogan, 1999; Silvera \& Austad 2004; O'mahony \& Meenaghan, 1998; Carneiro, 2002; Sengupta, Goodstein, \& Boninger, 1997; Leschnikowski, Schweizer, \& Drengner, 2006; Chao, Wuhrer, \& Werani, 2005; Kahle \& Homer, 1985; Till, Haas, \& Priluck, 2006; Batra \& Homer, 2004; Friedman, Santerano, \& Traina, 1978; Kirmani \& Shiv, 1998; Stafford, Stafford, \& Day, 2002; Goldsmith, Lafferty, \& Newell, 2000; Forehand \& Perkins, 2005; Choi, Lee, \& Kim, 2005; Hayward, Rindova, \& Pollock, 2004).

Choi, Lee and Kim (2005), Teich (2008) claim that consumer behavior can be planned and controlled. Celebrity endorsement is one of the strategies employed successfully by publicity agencies in their campaigns in order both to persuade consumers and to generate a significant positive impact on companies' financial results. The technique consists of employing celebrities with attractive qualities to promote products or services (Atkin \& Block, 1983; Erdogan, 1999; Pornpitakpan, 2003; Silvera \& Austad, 2004; Leschnikowski, Schweizer, \& Drengner, 2006; Hayward, Rindova, \& Pollock, 2004; Teich, 2008). According to Muniz (2006) and Milward Brown Brasil (2006), it is estimated that one quarter of all publicity campaigns run worldwide employ celebrity endorsement as a means of improving the image of a company's brand, thereby influencing consumer purchasing attitudes. Products associated with celebrities appear to have a greater impact on consumers than products that have never previously been associated with a celebrity. (Walker, Langmeyer, \& Langmeyer, 1992; Pornpitakpan, 2003).

The subject chosen has been investigated by countless researchers all over the world (Atkin \& Block, 1983; Mccracken, 1989; Walker, Langmeyer, \& Langmeyer, 1992; Sakellarides, 1999; Erdogan, 1999; Pornpitakpan, 2003; Silvera \& Austad, 2004; Choi, Lee, \& Kim, 2005; Leschnikowski, Schweizer, \& Drengner, 2006; Rindova, Pollock, \& Hayward, 2006). Studies conducted in Brazil by Andrade, Mazzon and Katz (2006), Boeing-da-Silveira, Marcon and Nascimento (2007) were designed to investigate the returns and effectiveness that can be expected by organizations that use celebrity endorsement in their marketing campaigns. These results of these studies reflected positively on the practice, despite not all analyzing the market from the same perspective. Notwithstanding, the subject has been explored little in Brazil.

Celebrities are people who are widely recognized by society, primarily because of positive attributes (Atkin \& Block, 1983). In the past, celebrities were recognized for their personal or professional merits, as with victorious generals, courageous heroes and religious leaders. These celebrities were admired for their feats, accomplishments, sacrifices or heroic acts (Sakellarides, 1999). Modern celebrities are media figures created by the publicity industry which turns unknowns into celebrities, emphasizing their qualities, with the objective of increasing the appeal of advertisements and so trigger positive emotional responses among the mass public (Sakellarides, 1999; Rindova, Pollock, \& Hayward, 2006).

Marketing professionals use a wide range of endorsers in their campaigns, including actors, musicians, comedians and sportsmen. Inanimate beings such as characters from fiction and cartoon characters are also often used. Recently, specialist professionals, CEOs, and other high-level employees have taken the stage as spokespeople in advertisements for the products or services of their companies. However, of all of these, using celebrities is the most popular strategy (Choi, Lee, \& Kim, 2005; Hayward, Rindova, \& Pollock, 2004).

Organizations invest significant amounts of money to make their brands stand out and to align them with endorsers. Notwithstanding the high costs involved, companies benefit from using celebrities, who offer the possibi lity of creating an association between their qualities and the brand or product advertised, thereby attracting the attention of consumers (Walker, Langmeyer, \& Langmeyer, 1992; Leschnikowski, Schweizer, \& Drengner, 2006).

Erdogam (1999) identified four advantages from using celebrity endorsement in advertising. However, Kaikati (1987) believes there are five advantages to be gained from using celebrity endorsement: the attractiveness of the source, the credibility of the source, that congruence between source and brand, transfer of culturally constituted meanings, and influence on the sales of the products they endorse.

The first benefit attributed to this tool is that a campaign employing celebrity endorsers helps to attract consumer attention to the product or brand being advertised from among the very large number of messages that consumers are exposed to every day (Mccracken, 1989; Erdogan, 1999; Silvera \& Austad, 2004; Boeing-da-Silveira, Marcon, \& Nascimento, 2007). According to Erdogan (1999), the attractiveness of the source refers to the importance of forming positive stereotypes with respect to the celebrity chosen, thereby shifting beliefs and creating an intention to purchase. It is important to point out that one component of attractiveness is similarity, which refers to the receiver's perception of attributes they have in common with the 
celebrity. The greater the number of attributes that the receiver feels they have in common with the celebrity, the more persuasive the message will be (Pornpitakpan, 2003; Silvera \& Austad, 2004).

The second advantage refers to the capacity that celebrities may have to rehabilitate a tarnished company image, in other words, a celebrity may be able to transmit credibility and respectability to consumers. For the source to be credible it must be both knowledgeable and reputable, in order to cultivate a positive attitude towards the brand, and credibility is one of the factors that will determine the effectiveness of the message (Mccracken, 1989; Erdogan, 1999; Matos \& Veiga, 2002; Pornpitakpan, 2003; Silvera \& Austad, 2004; Milward Brown Brasil, 2006; Dornelas, 2007). To put it another way, the elements of attractiveness and credibility are related to the spokesperson's knowledge and experience of a given product or service. Specialization is also a part of establishing credibility and refers to the source's capacity to make valid claims. Reliability is also necessary for credibility, and this refers to the belief that the source's claims are convincing and believable, and as such confers positive characteristics that affect whether the receiver of the message accepts it (Pornpitakpan, 2003).

A large proportion of the research carried out with the intention of aiding in the process of choosing celebrity endorsers is rooted in the theory about the effect that the source communicating the product will have. The theory is based on the idea that certain characteristics belonging to the celebrity and perceived by the receiver of the message have a beneficial effect. The source's credibility and capacity to attract are important characteristics that will affect the receiver's acceptance (Atkin \& Block, 1983; Silvera \& Austad, 2004).

However, using testimonials from famous people simply because of the power the technique offers, without concerning oneself with the appropriateness of the message leads to a loss of credibility, by breaking contact with reality (Guimarães, 2006; Leschnikowski, Schweizer, \& Drengner, 2006). The endorsing personality must have inspirational characteristics, which will vary depending on the company's business sector and, in addition to these, must actually consume the product they advertise because otherwise the celebrity's seal of approval will end up selling the product, but will not contribute to building brand identity due to a lack of consistency. Therefore, successful campaigns are the result of correctly matching the celebrity and the message to the brand, because when both celebrity and brand have values and followers in common, the benefits are multiplied, both for the brand and the celebrity (Milward Brown Brasil, 2006; Guimarães, 2006; Leschnikowski, Schweizer, \& Drengner, 2006).

The third advantage is related to congruence between the brand and the endorser, since the choice of celebrity must meet the criteria of the public identifying the product with the public figure, which will determine whether the celebrity's attributes are actually transmitted to the end consumer (Silvera \& Austad, 2004). This model is also known as "match-up" and it is based on the claim that the celebrity's image and the product message must be congruent for the advertising to be effective, which can be put another way-the success of the celebrity-brand combination depends on the degree of perceived match-up between the two elements (Pornpitakpan, 2003; Silvera \& Austad, 2004; Leschnikowski, Schweizer, \& Drengner, 2006).

The transfer-of-meanings model is another factor influencing consumers, by which culturally constituted characteristics belonging to the celebrity are transferred to the products. The principle of global marketing involves the capacity of an organization to sell its product in the same way all over the world. Celebrities can be helpful for breaking down cultural barriers which could prevent a product from being successful in a foreign market or make that success more difficult to achieve. (Erdogan, 1999). Erdogan, Baker and Tagg (2001) and Andrade et al. (2006) argue that the use of celebrities in publicity campaigns is because they increase impact and offer the chance for those advertising to establish empathy with their public, in addition to increasing the likelihood of achieving returns in terms of Publicity and Public Relations.

New brands or products can be launched using a celebrity, or a celebrity can help create a new public image for a brand or products that already exists, but has not yet been endorsed. A brand's image is the perception that its customers or consumers and the general public have of it. A brand can create certain associations in the minds of its consumers and this can have an enormous impact on purchasing decisions (Aaker, 1996). The choice of a celebrity endorser for a publicity campaign can add value to a brand and even create a distinct identity, using attributes for which that celebrity is already known and famous and which the consumer can perceive as serving as a foundation for the construction of the brand's image (Mccarthy \& Perreaut, 1997; Muniz, 2006; Milward Brown Brasil, 2006). The fifth and final major advantage of using a celebrity endorser in publicity campaigns is of course that they help to improve the sales of the products they are promoting (Pornpitakpan, 2003).

The potential risks associated with using a celebrity endorser are also very high, since organizations have very little control over the characteristics of the endorser who will have created their public image over the years. 
Furthermore, if the celebrity endorser becomes controversial due to negative behavior this can potentially create risks for the company and its products (Pornpitakpan, 2003; Silvera \& Austad, 2004).

Good marketing campaigns require careful market research, both of the products and of the people. There are, however, certain differences. Products, obviously, are more easily managed. People exhibit often exhibit an unpredictability that can interfere with efforts to transform them into celebrities (Sakellarides, 1999). Any type of negative publicity about a celebrity can reduce the fascination that they exert and the appeal of the brand that they endorse (Pornpitakpan, 2003; Boeing-da-Silveira, Marcon, \& Nascimento, 2007).

The stars who are most sought-after for endorsement are those who do not get themselves involved in scandals, which proves the high risk of these partnerships, since it is impossible to control all of a celebrity's attitudes outside of the commercial in which they are acting as a company spokesman (Guimarães, 2006). When choosing a celebrity endorser it is necessary to take into consideration not only the characteristics that are related to and will be transferred to the product, but also the widest possible meanings that could be associated with the endorser. While a given endorser may have certain characteristics that are desirable for endorsing a given product, he or she may also have other attributes that are inappropriate for that product, leading to the target public not identifying with the characteristics projected (Walker, Langmeyer, \& Langmeyer, 1992; Leschnikowski, Schweizer, \& Drengner, 2006).

The consumers will feel more motivated to purchase products that have been endorsed by a celebrity than products that are not advertised by celebrities. If the product to be marketed involves social risks (there is a chance that the use of this product may affect what other people think about the consumer) or psychological risks (there is a chance that the product will not sit well with the consumers self-image), then the advertiser should consider using a celebrity endorser. Freiden (1984) concludes that celebrity endorses are particularly effective because they are seen as highly trustworthy, believable, persuasive and lovable.

The issue of celebrities endorsing more than one product at the same time was studied in research conducted by Tripp et al. (1990), who compared the reaction of consumers to celebrities who promote just one product with the reaction of consumers to multiple endorsements by the same celebrity. The results of the study have practical implications for marketing professionals when selecting an endorsing celebrity. Both purchasing intentions and attitudes of those surveyed were more favorable when the celebrity endorser had never supported a product before; i.e., consumers reacted more favorably when a celebrity endorser did not have a previous history of endorsement. These results underline the importance of advertisers signing exclusive deals with celebrities. A study carried out by Tripp (1990) reinforces the idea that a celebrity who supports more than one product will be perceived as less creditable, reliable and likeable than a celebrity who only endorses one product (Silvera \& Austad, 2004).

The results of all of these studies show that it is important to realize that advertisers need to exert greater effort when choosing endorses to ensure that they match up with the product being advertised and should seek exclusivity, since consumers react more favorably to celebrities who only endorse one product than to celebrities who endorse multiple products. Furthermore, it is important that the celebrity be seen with the brand regularly and repeatedly, thereby influencing purchasing decisions by the immediate association, which should be promoted with strong arguments which truly justify the product endorsement (Silvera \& Austad, 2004; Leschnikowski, Schweizer, \& Drengner, 2006).

The use of celebrity endorsement is an effective publicity tool for promoting products and brands in the widest range of media. This is a tool that is capable of influencing consumer perceptions and behavior with relation to a company or brand, thereby increasing market value (Walker, Langmeyer, \& Langmeyer, 1992). The publicity industry attempts to understand consumer behavior in order to find the most effective communication methods, with the objective of influencing the market to give preference to a given organization to provide its products and services (Mccarthy \& Perreaut, 1997; Matos \& Veiga, 2002).

\section{Methodology}

The objective of this exploratory, descriptive research with quantitative data analysis was to analyze the true contribution of celebrity endorsement to the purchasing behavior of consumers in a town in the South of Brazil.

The data collection instrument was a structured questionnaire administered to consumers who were approached in the center of this South Brazilian town and who comprised the study population of this research. The questionnaire was developed on the basis of concepts described by Erdogam (1999), Silvera and Austad (2004), Leschnikowski, Schewizer and Drengner (2006), Teigh (2006), who all state that publicity campaigns which use celebrities with attractive qualities to promote products or services are capable of modifying consumer 
purchasing behavior.

Data were collected during the summer vacations, meaning that the study population is infinite, since in addition to its residents, this city is visited by consumers from the region and tourists from all over the world, who go shopping there. The data needed to achieve the research objectives was collected from a sample of 400 consumers recruited in the town in South Brazil, selected to meet the research requirements. The sampling technique was probabilistic, by accessibility, where each consumer has an equal probability of being selected.

The minimum sample size calculated was 369 consumers, surveyed in the center of the town chosen for the fieldwork. In order to obtain more consistent results, the sample size was increased to 400 questionnaires. The data collection instrument underwent a pilot study at $8 \%$ of the size of the main sample (32 questionnaires). The response options on the questionnaire were arranged in a five-point Likert scale.

The questionnaire was subdivided into two sections, the first comprising questions intended to profile the interviewees according to five variables and their subcategories. The second section collected the data on celebrity endorsement, comprising twenty closed questions covering ten themes, with two questions dealing with each theme. This technique made it possible to obtain the consumers' opinions more precisely and also their level of understanding of each of the themes. The themes covered and the questions dealing with each are listed in Table 1.

Table 1. The ten themes covered and the questions dealing with them

\begin{tabular}{cc}
\hline Theme & Questions \\
\hline Celebrity endorsement & 8 \\
& 20 \\
Attractiveness of the source & 7 \\
Famous/unknown & 17 \\
& 10 \\
Negative image & 18 \\
& 3 \\
Credibility & 13 \\
& 16 \\
Celebrity/advertiser match-up & 6 \\
& 5 \\
Transfer of meanings & 15 \\
& 4 \\
Repetition of the message & 14 \\
& 12 \\
Consumer behavior & 19 \\
& 1 \\
Consumer perceptions & 11 \\
\end{tabular}

\section{Analysis of the Results}

The analysis was conducted in two stages. In the first stage, the population was treated in accordance with the concept described by Barbetta (2001), which relates to the number of elements desirable to achieve the objectives proposed for the study, i.e., this analysis was based on all 400 replies to each of the 20 questions. In the second stage, described in subsection 4.2 below, the replies from specific population subsets were analyzed.

Working on the basis of Kotler's (2003) opinion that analysis and study of the profile of target publics allows marketing professionals to identify the interests of purchasers and to align them to the factors that have an influence on consumers' purchasing process, thereby creating products and appeals which better meet customers' requirements, the consumer profile was traced using five variables: sex, age (subdivided into eight age groups), marital status (subdivided into five possibilities); educational level (subdivided into seven levels of graduation); personal income (subdivided into eight bands).

Based on the most frequently occurring categories, a profile was traced of the most common personal features in the interviewee sample. The sexes were very balanced in this sample, with $48 \%$ males and $52 \%$ females. There 
was considerable variation within the replies to the other four categories, with the most common profile being a resident of the town where the interviews were conducted, aged between 18 and 25 , single, a university student and with a monthly income between income $\mathrm{R} \$ 1,001.00$ and $\mathrm{R} \$ 1,500.00$. The percentage of the sample in each subdivision of each of the five categories is given in Figure 1.

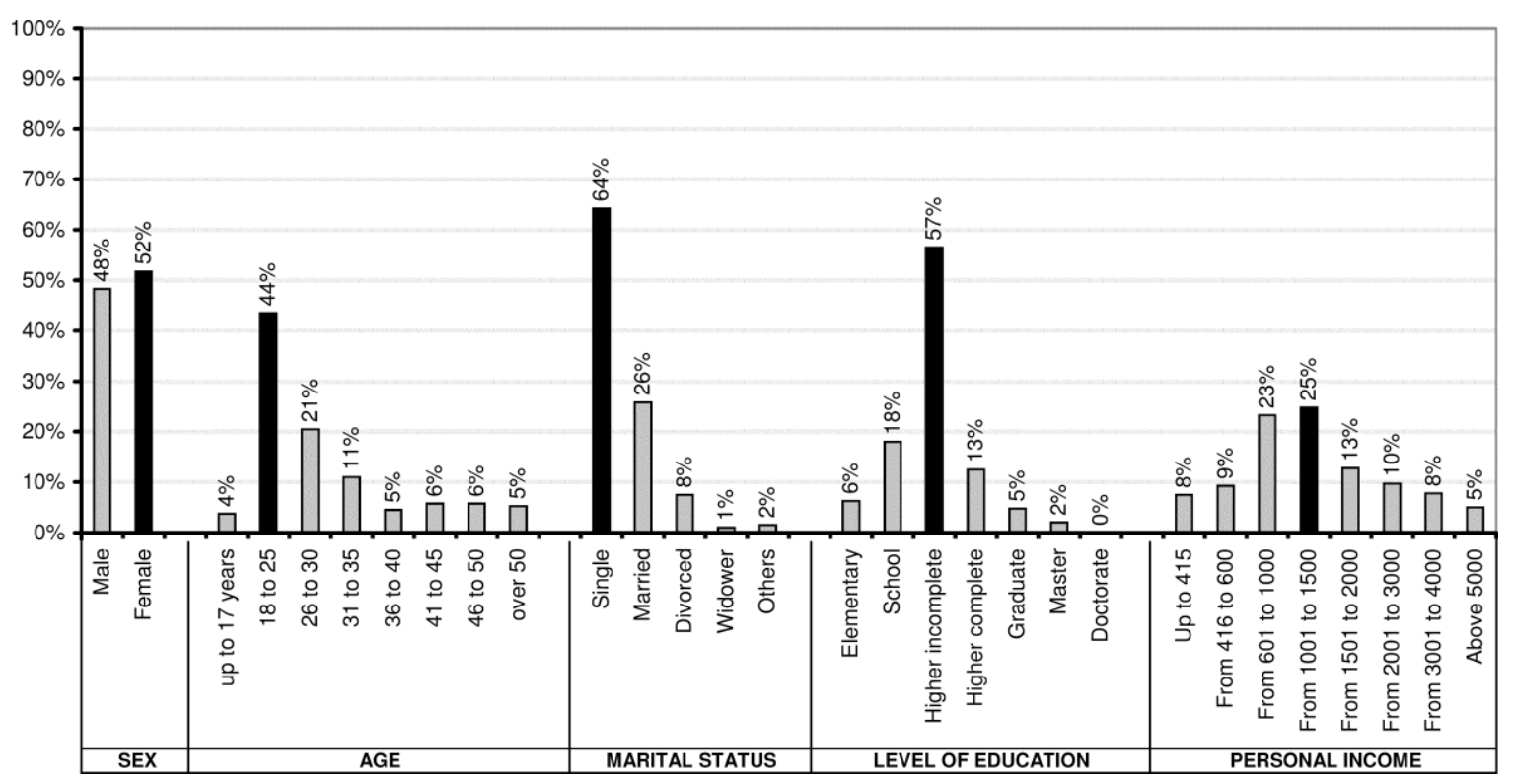

Figure 1. Graph of the personal profiles of the study sample

With the intention of situating the perceptions of the consumers in a town in South Brazil with relation to theories that support celebrity endorsement, 10 theories related to the use of endorsement as a strategy were incorporated into the data collection instrument. In order to facilitate extraction of consumer opinion and to verify any possible distortions in the results, two questions were included related to each theory, and analysis was based on pairs of questions, each relating to the same theme. The 10 theories and the questions referring to each theory are listed in Table 2 below.

The results of analyses will be presented as arithmetic means, standard deviations and frequencies. Table 2 lists the absolute frequencies for each question for the whole set of 400 people. The figures highlighted in Table 2 are the highest frequencies for each question.

Table 2. Absolute frequencies for each question for the entire sample of 400 people

\begin{tabular}{c|c|c|c|c|c|c|c|c|c|c|c|c|c|c|c|c|c|c|c|c}
\hline QUESTION & $\mathbf{0 1}$ & $\mathbf{0 2}$ & $\mathbf{0 3}$ & $\mathbf{0 4}$ & $\mathbf{0 5}$ & $\mathbf{0 6}$ & $\mathbf{0 7}$ & $\mathbf{0 8}$ & $\mathbf{0 9}$ & $\mathbf{1 0}$ & $\mathbf{1 1}$ & $\mathbf{1 2}$ & $\mathbf{1 3}$ & $\mathbf{1 4}$ & $\mathbf{1 5}$ & $\mathbf{1 6}$ & $\mathbf{1 7}$ & $\mathbf{1 8}$ & $\mathbf{1 9}$ & $\mathbf{2 0}$ \\
\hline $\begin{array}{c}\text { STANDARD } \\
\text { DEVIATION }\end{array}$ & $\mathbf{1 . 1 9}$ & $\mathbf{1 . 2 7}$ & $\mathbf{1 . 2 3}$ & $\mathbf{1 . 3 2}$ & $\mathbf{1 . 3 4}$ & $\mathbf{1 . 3 4}$ & $\mathbf{1 . 2 9}$ & $\mathbf{1 . 2 8}$ & $\mathbf{1 . 3 0}$ & $\mathbf{1 . 4 4}$ & $\mathbf{1 . 3 3}$ & $\mathbf{1 . 3 0}$ & $\mathbf{1 . 3 4}$ & $\mathbf{1 . 2 3}$ & $\mathbf{1 . 2 5}$ & $\mathbf{1 . 1 9}$ & $\mathbf{1 . 3 4}$ & $\mathbf{1 . 2 2}$ & $\mathbf{1 . 2 3}$ & $\mathbf{1 . 2 4}$ \\
\hline \\
\hline
\end{tabular}

As can be observed in Table 2, one of the extremes of the Likert scale had the greatest absolute frequency of responses in questions $04,05,09,10,11$ and 17 . Were the method of arithmetic means to have been used, these same questions would be rated as indifferent or one of the tangents, as is indicated by the standard deviation, which is never lower than 1.3, suggesting that there was a wide distribution in these questions. For this reason, using arithmetic means alone, an important portion of differing opinions would have been. Nevertheless, the fact 
that the greatest absolute frequency was recorded for a different concept from that which would have been identified using means, does not mean that either of the two analyses are conclusive. On the contrary it merely brings one extra doubt into the research, about which method should be accepted.

In response to this, in an attempt to answer the question of which of these two methods is most appropriate for the analysis, arithmetic means or absolute frequency, three filters were constructed aiming to measure whether there was a tendency, or a considerable majority among replies, since there was a diffuse distribution, detected by the standard deviation. Filter 1 , which is represented in Table 3, compares the concept with the highest relative frequency with the concept selected using arithmetic means, for each of the twenty questions.

Table 3. Comparison between concepts chosen most often and those chosen by arithmetic means

\begin{tabular}{c|c|c|c|c|c|c|c|c|c|c|c|c|c|c|c|c|c|c|c}
\hline 01 & 02 & 03 & 04 & 05 & 06 & 07 & 08 & 09 & 10 & 11 & 12 & 13 & 14 & 15 & 16 & 17 & 18 & 19 & 20 \\
\hline$=$ & $\neq$ & $=$ & $\neq$ & $\neq$ & $\neq$ & $=$ & $\neq$ & $\neq$ & $\neq$ & $\neq$ & $=$ & $=$ & $\neq$ & $\neq$ & $=$ & $\neq$ & $\neq$ & $\neq$ & $=$ \\
\hline
\end{tabular}

\begin{tabular}{|c|c|c|c|c|c|c|c|c|c|c|c|c|c|c|c|c|c|c|c|c|}
\hline \multirow{2}{*}{ 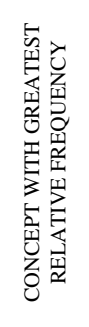 } & iे & $\stackrel{\circ}{\circ}$ & ळ̊ & 字 & 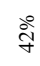 & $\stackrel{8}{\circ}$ & 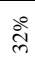 & $\stackrel{8}{d}$ & 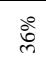 & $\stackrel{\circ}{\stackrel{\infty}{\sim}}$ & $8_{i}^{\circ}$ & $\frac{\delta^{\circ}}{m}$ & த̊ & $\frac{\stackrel{\circ}{f}}{m}$ & $\stackrel{8}{\circ}$ & $\stackrel{\Im}{\Im}$ & $\stackrel{\circ}{m}$ & $\stackrel{8}{\circ}$ & ळे & हे \\
\hline & 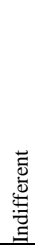 & 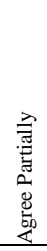 & 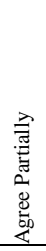 & 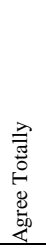 & 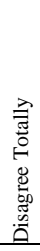 & 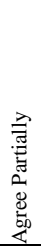 & 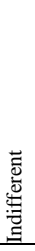 & 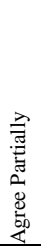 & 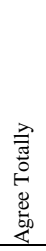 & 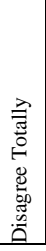 & 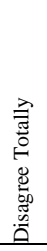 & 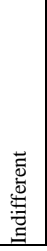 & 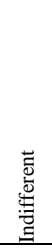 & 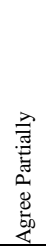 & 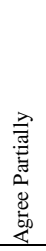 & 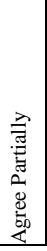 & 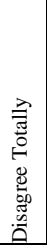 & 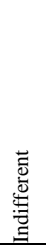 & 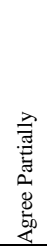 & 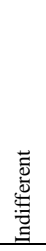 \\
\hline $\begin{array}{l}\text { Standard } \\
\text { Deviation }\end{array}$ & $\stackrel{9}{\leftrightarrows}$ & $\widehat{\stackrel{I}{I}}$ & $\stackrel{\overbrace{}}{త}$ & $\stackrel{\overbrace{}}{-}$ & $\stackrel{+}{\mathrm{m}}$ & $\stackrel{+}{-}$ & તે & $\stackrel{\infty}{\stackrel{\sim}{\longrightarrow}}$ & $\stackrel{\text { m) }}{-}$ & $\stackrel{\text { J }}{\text { 专 }}$ & $\stackrel{m}{9}$ & $\stackrel{\overbrace{}}{i}$ & 范 & $\stackrel{\overbrace{}}{త}$ & $\stackrel{\overbrace{}}{\mathfrak{I}}$ & $\stackrel{9}{\leftrightarrows}$ & $\stackrel{m}{m}$ & 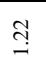 & $\stackrel{\overbrace{}}{=}$ & $\stackrel{\text { İ }}{=}$ \\
\hline
\end{tabular}

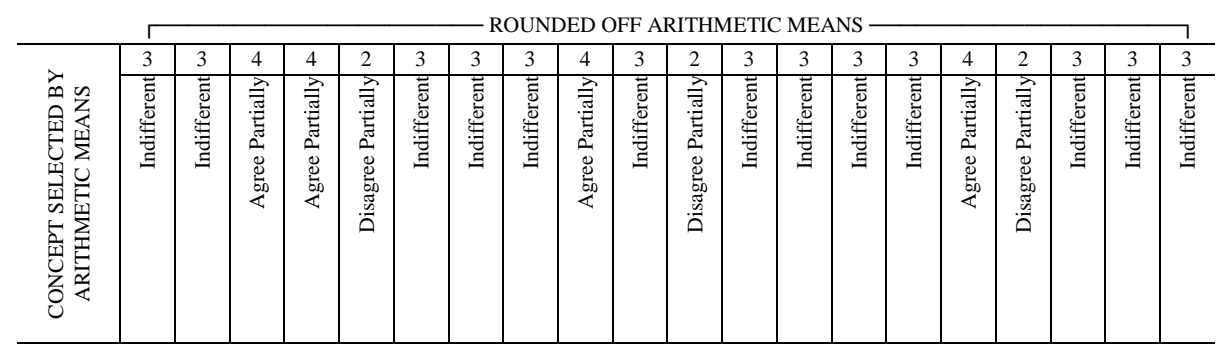

Filter 2, which is represented in Table 4 compares the concept with the greatest absolute frequency (A) with the concept with the second greatest absolute frequency (B). Dividing A by B, one obtains the ratio of how many times the most frequent concept is more frequent than the second most frequent concept.

Applying this filter already makes it possible to reach a conclusion on some of the questions. In question 23, the concept with the greatest absolute frequency is indifferent, which, in addition to having been selected by arithmetic mean and by the frequency method, was also chosen 2.2 times more often than the second most often chosen concept, which is absolute agreement. However, there is still a gap in the analysis, originating from the Likert scale, which allows individuals to choose between 2 degrees of agreement or disagreement. Filter 3 was constructed in order to fill this gap.

Filter 3 is represented in Table 5, where the 2 degrees of agreement are taken together, and the 2 degrees of disagreement are similarly grouped, and the results compared. This can be done because, although people were given the option of agreeing or disagreeing partially or totally, the fact remains that they are still agreeing or disagreeing to some extent or another. 
Table 4. Questions where the most frequent reply is more than twice as frequent as the next most frequent

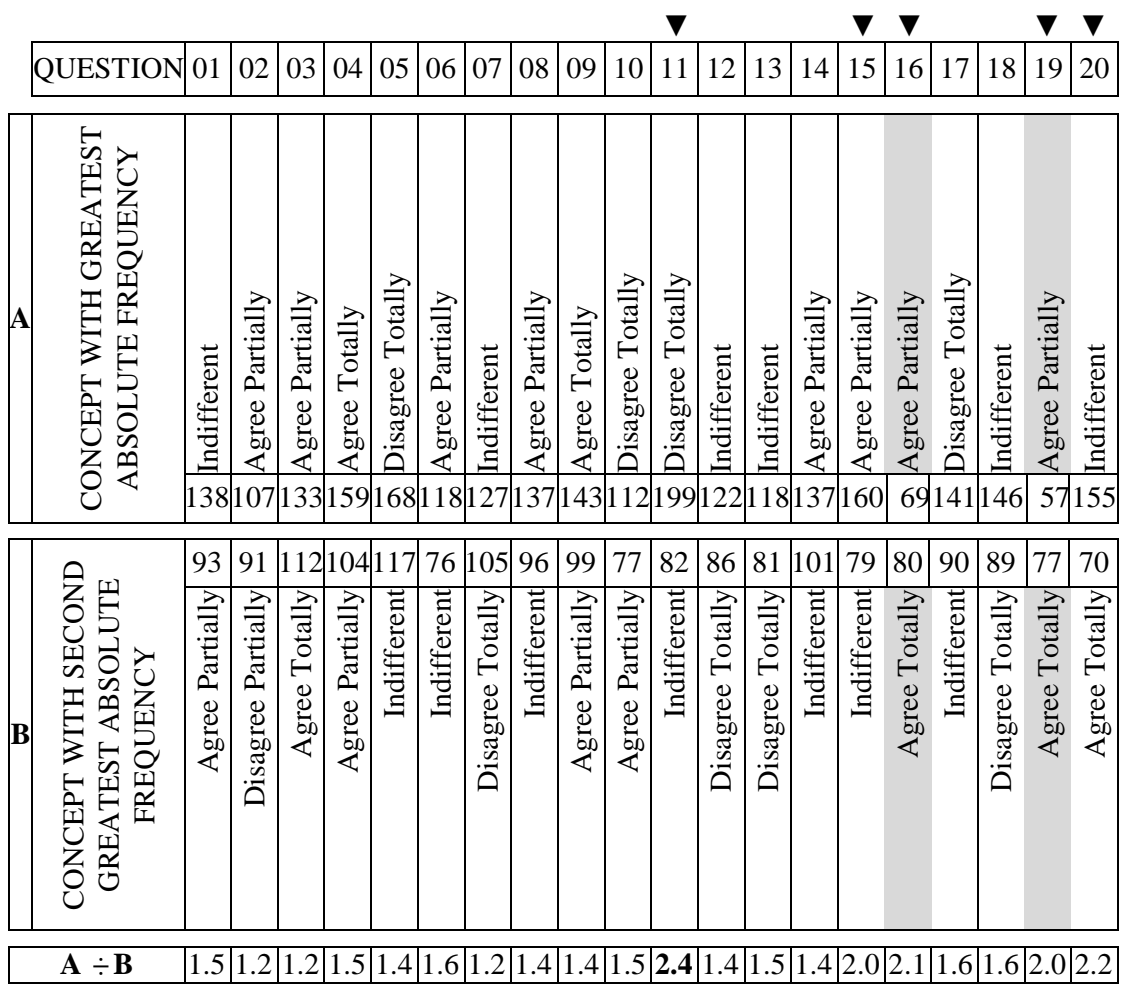

Table 5. Comparison of frequencies of two concepts "agreement" and "disagreement"

\begin{tabular}{|c|c|c|c|c|c|c|c|c|c|c|c|c|c|c|c|c|c|c|c|c|}
\hline & & & $\nabla$ & $\nabla$ & $\nabla$ & & & & $\nabla$ & & $\nabla$ & & & & $\nabla$ & $\nabla$ & $\nabla$ & & $\nabla$ & \\
\hline Question & 01 & 02 & 03 & 04 & 05 & 06 & 07 & 08 & 09 & 10 & 11 & 12 & 13 & 14 & 15 & 16 & 17 & 18 & 19 & 20 \\
\hline 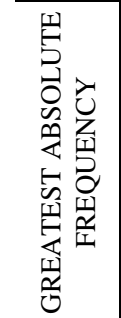 & 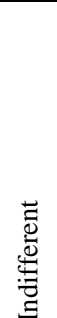 & 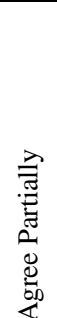 & 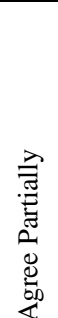 & 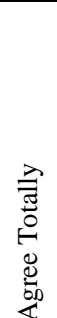 & 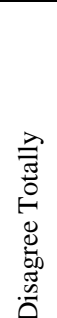 & 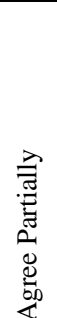 & 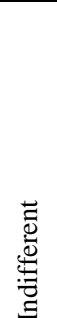 & 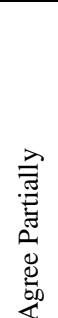 & 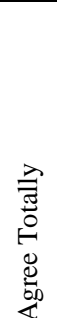 & 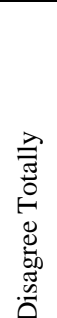 & 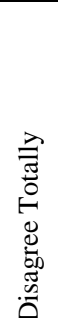 & 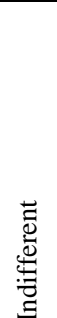 & 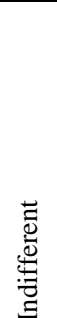 & 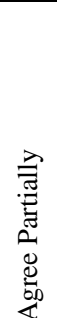 & 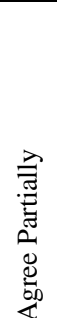 & 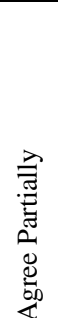 & 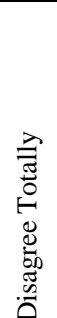 & 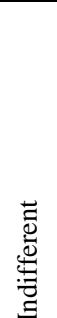 & 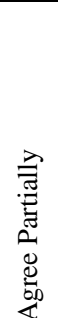 & 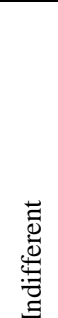 \\
\hline
\end{tabular}

\begin{tabular}{|c|c|c|c|c|c|c|c|c|c|c|c|c|c|c|c|c|c|c|c|c|}
\hline \multirow[t]{2}{*}{ Disagree } & $\begin{array}{l}\text { के } \\
\text { nे }\end{array}$ & $\stackrel{\circ}{\stackrel{0}{m}}$ & ठ̊ํ & $\frac{\pi}{2}$ & $\begin{array}{l}0 \\
\text { 号 } \\
\end{array}$ & 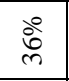 & $\frac{80}{\gamma}$ & ते & ڤ̊ำ & 通 & हீ & $\frac{\circ}{\infty}$ & 㤐 & $\stackrel{\circ}{\stackrel{\circ}{*}}$ & $\begin{array}{l}\stackrel{2}{a} \\
\text { in }\end{array}$ & $\frac{\pi}{2}$ & 离 & $\begin{array}{l}\stackrel{0}{\infty} \\
\infty \\
\end{array}$ & i̊ & $\stackrel{\circ}{\stackrel{\circ}{*}}$ \\
\hline & 139 & 137 & 81 & 82 & 215 & 144 & 165 & 117 & 81 & 185 & 250 & 149 & 140 & 109 & 101 & 85 & 215 & 152 & 100 & 108 \\
\hline
\end{tabular}

\begin{tabular}{|c|c|c|c|c|c|c|c|c|c|c|c|c|c|c|c|c|c|c|c|c|}
\hline \multirow[b]{2}{*}{ Agree } & 123 & 175 & 245 & 263 & 68 & 180 & 108 & 187 & 242 & 140 & 68 & 129 & 142 & 190 & 220 & 249 & 95 & 102 & 234 & 137 \\
\hline & $\frac{\partial}{m}$ & $\stackrel{\stackrel{\circ}{f}}{\dot{f}}$ & $\frac{8}{6}$ & )̊̊ & $\stackrel{\circ}{\beth}$ & $\stackrel{8}{i}$ & 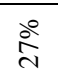 & $\frac{\stackrel{2}{\sigma}}{8}$ & $\frac{8}{6}$ & $\stackrel{\circ}{n}$ & $\stackrel{2}{\beth}$ & $\stackrel{\circ}{\text { ๙े }}$ & do & 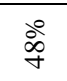 & $\begin{array}{l}0^{\circ} \\
\text { in }\end{array}$ & ปิ & $\stackrel{\stackrel{\leftrightarrow}{\sim}}{\mathrm{d}}$ & :̊ㅇㅇ & i̊ & $\frac{\stackrel{8}{4}}{4}$ \\
\hline
\end{tabular}

These consumers agreed that controversial behavior by celebrities can have a negative influence on their choice of product. Furthermore, they agreed that there is a high risk involved in associating a celebrity with a brand, which supports the theory about negative celebrity images supported by Pornpitakpan, (2003) and Silvera and 
Austad, (2004), who claim that the potential risks associated with the use of a celebrity endorser are very high since organizations have limited control over their characteristics.

According to the theory of the advantages of using celebrities in commercials, as supported by Mccraken (1989), Erdogan (1999), Kaikati (1987), Silvera and Austad (2004) and Boeing-da-Silveira, Marcon and Nascimento (2007), in general people sympathize with celebrities in commercials or advertisements, which supports the idea that campaigns employing celebrity endorsers help to attract consumers' attention to the product or brand which is being advertised amidst the very large number of messages to which consumers are exposed every day.

The fact that some people are indifferent to products or brands endorsed by celebrities does not mean that they are against them advertising products, and so it is reasonable to state that while a celebrity may not make all the difference to the sales of products, their presence in a campaign does not generally impact it negatively.

The consumers' opinions on the model of the attractiveness of the source was, in general, the opposite of what Erdogan (1999) describes, when he suggests that a celebrity endorser who has an attractive stereotype will influence consumers' purchasing decisions, attracting attention to the product being advertised.

Our results demonstrate that the fact that the product is endorsed by a celebrity does not influence the purchasing decisions of the public surveyed. Therefore, it is reasonable to claim that factors related to the marketing mix, such as product accessibility, perceived quality, competitive pricing and innovative campaigns (Kother, 1999; Ferreira, 2003; Menshhein, 2006) are more relevant to consumers than endorsement.

On the basis of the most frequently recurring responses, whereby celebrities have the capacity to rehabilitate a stained company image; i.e., celebrities can transmit credibility and respectability to society. Nevertheless, Pornpitakpan (2003) also point out that, in order for this to happen, celebrities must be making convincing and believable claims, and thereby confer positive characteristics which will affect consumers' acceptance of the product being endorsed.

In order for a campaign to successfully change the attitudes of consumers, it is necessary that the public identify the products with the public figure, i.e., it is necessary that there be an affinity between products and endorser, for the celebrity's attributes to be truly passed to the final consumer (Walker, Langmeyer, \& Langmeyer, 1992; Leschnikowski, Schweizer, \& Drengner, 2006). Our consumers stated that they did think it was important for the celebrity to match the product they advertise, but they did not consider it important that the celebrity actually consumed what they were advertising. This perhaps explains why it is common for Formula One drivers to promote cigarette brands and football players to be seen advertising beer.

For our consumers, the strategy of celebrity endorsement was also confirmed as a strong ally for breaking down cultural barriers that could prevent or make it difficult for a product to be successful in a foreign market (Erdogan, 1999). Globalised trade demands that organizations be capable of selling their products in the same way all over the world and celebrities who have culturally constituted characteristics that can be transferred to products are helpful in such scenarios.

People buy products that appear frequently in the media, whether endorsed by celebrities or not, as a result of the immediate association created with strong arguments used in the commercial to justify the benefits associated with acquiring the product (Silvera \& Austad, 2004; Leschnikowski, Schweizer, \& Drengner, 2006). It therefore appears reasonable to claim that consumers are more influenced by frequently-repeated commercials than they are by celebrity-endorsed commercials.

Kotler (2003) declares that consumers' internal and external psychodynamic factors can be worked-on, in order to alter their purchasing behavior. However, our research has shown that the consumers we studied do not feel themselves to be influenced by these factors. Consumers feel more enthusiastic about buying products that are marketed in their natural habitat than about buying products that are consumed by a given group of reference (Schiffman \& Kanuk, 1997). They either appear not to be interested in status or not to believe that purchasing products advertised by celebrities is a good way of increasing their status among their peers.

There was a certain degree of contradiction among the interviewees in terms of their perceptions of the use of celebrity endorsement in advertisement and it therefore appears definitive to state that a traditional brand is preferred by consumers over a brand advertised by a celebrity. Although the interviewees agreed with both precepts, they contradicted themselves within the concept, because, at the same time as they said they were indifferent to the appeal of celebrities, they did agree that a celebrity who advertises several products can have a negative impact on the products they are advertising. In other words, they actually do care about the presence of a celebrity, even if in the sense of impacting negatively on the product rather than positively.

In our second stage of analysis, we treated the population in line with concepts supported by Malhotra 
(2001), who describes populations as a collection of elements which have certain characteristics in common, i.e., we analyzed just those replies provided by groups of interviewees with similar profiles such as, for example, only single people, just men, and so on. This stage of the analysis was undertaken with the objective of identifying possible divergences between the average profile and specific profiles. It also attempted to identify differences in opinion between different populations on the same question. Therefore, subsets with similar profiles will be compared, but the statistical analysis applied will not be so complex, employing only the arithmetic means as instrument of comparison. Results will be compared between subsets and with the means for the whole sample.

Subsets were selected on the basis of three variables: sex, marital status and monthly income. The other two variables, age and educational level, were not used to define subsets since, in both cases, a single category corresponding to $60 \%$ of the sample and so it would have been irrelevant to analyze them.

When the sample was divided by sex, women proved more sensitive to the appeal of celebrities with positive stereotypes and with credibility. The men's replies gave more support to frequently-repeated advertisements than to celebrity endorsement. The results support the statement that women, and also people with higher incomes, are more sensitive than men to the appeal of marketing using credible celebrities to create a positive attitude towards the brand. Perhaps this is why it is rare to see recently-famous celebrities endorsing consumer durables.

\section{Final Comments}

In the course of this research 10 themes were investigated in order to delineate the perceptions of the consumers at the city studied, in the south of Brazil, of the advantages of using celebrity endorsement in advertising. Where replies to specific themes differed between individual questions, a more detailed analysis was necessary in order to identify the interviewees' opinions. Notwithstanding, their replies are presented with fidelity.

Only the theories of the credibility of the source and of transfer of meanings confirmed the advantages of using an endorser as being a factor with a strong influence, in the perceptions of those interviewed, thereby influencing their purchasing decisions. The theory of celebrity endorsement and the theory of matching a celebrity to a commercial were also indicated as factors influencing the purchasing decisions of those interviewed, although the results were not nearly so clear-cut.

The answers relating to the theories of attractiveness of the source, repeated messages and endorsement by celebrities or unknowns were, to a certain extent contradictory, demanding a more detailed analysis in order to elucidate the interviewees' opinions. Frequently repeated advertisements for products, whether endorsed by a celebrity or not, make a greater impression with the interviewees, particularly the men, due to the strong and immediate association with robust arguments used in commercials, than do advertisements made by a celebrity, within a short product lifecycle.

The consumers in the town studied do not believe that famous people induce them to consume by attracting their attention to the product they are advertising. This statement is particularly valid for the men and married people and only for the subset with higher spending power. The population with lower spending power was indifferent. This explains why the majority of commercials that are segmented for women are endorsed by celebrities with positive stereotypes.

Our consumers claimed to be indifferent to whether a product is endorsed by a celebrity or an unknown. They also considered that factors related to the marketing mix, such as product accessibility, perceived quality, a competitive price and innovative campaigns (Kother, 1999) were more relevant to determining the effectiveness of an advert than the presence of a celebrity endorser.

The three remaining theories: consumer behavior, consumer perceptions and negative image; had definitive results, but were not confirmed by the consumers of the researched city as factors influencing their purchasing decisions.

On the basis of the results of this research, it is concluded that celebrity endorsement does influence the perceptions and purchasing behavior of consumers in the investigated city in Brazil. The model of the advantages of using celebrity endorsement is not entirely applicable to the sample as a whole, since three of the 10 theories investigated were not considered factors determining purchasing choices. A further three theories had contradictory concepts, which means that there was no definitive response. And, finally, four of the theories remained, confirmed in the opinion of those interviewed as strong influencing factors on purchasing decisions, and therefore marketing professionals should concentrate on these in order to develop feasible and successful campaigns, thereby accruing perceptible benefits to the company. 
This research has revealed a series of new correlations between concepts and variables. Celebrity endorsement has countless implications for consumer perception and some suggestions for future research into this relationship are as follows: analyzing the results of this research using representative cases of situations in which these concepts have been employed, with or without success; applying more robust statistical methods in order to obtain more definitive results and investigating the motives that lead companies that own endorsed brands to use a different strategy are all unmissable opportunities for studies to develop new knowledge about the subject.

Within the subsets divided by marital status, single people said they were more influenced by the attractiveness of the source than married people were. However, single people felt that if a celebrity was controversial outside of the commercial, it would still have a negative influence on the perception consumers have of the brand. In order to facilitate analysis by income, the consumers were grouped into three income bands: a low income population, a middle income population and a higher income population. The subset of low-income consumers stated that famous people made them more likely to consume, by attracting their attention to the products they advertise. The middle and high-income subsets only felt influenced when the endorsing celebrity transmits confidence and credibility.

The use of celebrities in advertisements has become in recent years one of the most used tools for dissemination of advertising, especially in first world countries. According to a study prepared by Brown cited Ibope, (2006), the celebrities are present in $12 \%$ of large advertising campaigns disseminated worldwide, and in Brazil is around $8 \%$. Japan leads the ranking of countries that use famous people in their campaigns, reaching $23 \%$ of the total.

In Brazil this strategy has grown a lot, mainly because of improving the image of a company's brand, and so naturally attract the attention and focus of the consumer. There are few studies on the subject, making it difficult to obtain data that were more related to the research, which was the biggest limitation of this work. Besides, getting the sample number was also difficult, since the approach happened in the summer time, when people weren't not as available as they would be in other periods of time.

Through this work, the range of new concepts and correlations among variables were expressed. As suggestions for future research, we address: To analyze the results of this research using demonstrative cases to situations where these concepts have been employed successfully or unsuccessfully; to use more robust statistical treatment as means of obtaining more conclusive answers; To investigate the reasons why some brands use this strategy.

\section{References}

Aaker, D. A. (1996). Criando e administrando marcas de sucesso. São Paulo: Futura.

Andrade, J., Mazzon, J. A., \& Katz, S. (2006). Você viu o vídeo do Ronaldinho? Uma reflexão a respeito da associação entre marcas e celebridades e o uso do marketing viral como ferramenta de comunicação de marketing. XXX ENANPAD, Salvador, 2006, Anais.

Atkin, C., \& Block, M. (1983). Effectiveness of celebrity endorsers. Journal of Advertising Research, 23(1), $57-61$.

Batra, R., \& Pamela, H. (2004). The situational impact of brand image beliefs. Journal of Consumer Psychology, 14(3), 318-330. http://dx.doi.org/10.1207/s15327663jcp1403_12

Boeing-da-Silveira, R., Marcon, R., \& Nascimento, H. (2007). Se ela usa eu uso. XXXI ENANPAD, Rio de Janeiro, 2007, Anais.

Carneiro, M. A. (2002). A utilização de celebridades e o múltiplo endosso na propaganda. Doctoral dissertation, Pontifícia Universidade Católica do Rio de Janeiro-PUC-Rio.

Chao, P., Gerhard, W., \& Thomas, W. (2005). Celebrity and foreign brand name as moderators of country-of-origin effects. International Journal of Advertising, 242(2), 173-192.

Choi, S. M., Lee, W. N., \& Kim, H. J. (2005). Lessons from the rich and famous: a cross-cultural comparison of celebrity endorsement in advertising. Journal of Advertising, 34(2), 85-98. http://dx.doi.org/10.1080/00913367.2005.10639190

Erdogan, B., Baker, M., \& Tagg, S. (2001). Selecting celebrity endorsers: The practioner's perpesctive. Journal of Advertising Research, 41(3), 39-48.

Erdogan, B. (1999). Celebrity Endorsement: a literature review. Journal of Marketing Management, 291-314. http://dx.doi.org/10.1362/026725799784870379 
Forehand, M. R., \& Andrew, P. (2005). Implicit assimilation and explicit contrast: a set/reset model of response to celebrity voice-overs. Journal of Consumer Research, 32(Dec), 435-441. http://dx.doi.org/10.1086/497555

Friedman, H., Michael, J. S., \& Anthony, T. (1978). Correlates of trustworthiness for celebrities. Academy of Marketing Science, 6(Fall), 291-299. http://dx.doi.org/10.1007/BF02732313

Goldsmith, R. E., Barbara, A. L., \& Stephen, J. N. (2000). The impact of corporate credibility and celebrity credibility on consumer reaction to advertisements and brands. Journal of Advertising, 29(Fall), 43-54.

Guimarães, R. (2006). Marcas com personalidades: Executivos de marketing apontam os prós e os contras no uso de celebridades em campanhas publicitárias. Revista Marketing.

Hayward, M., Rindova, V., \& Pollock, T. (2004). Believing one's own press: the causes and consequences of CEO celebrity. Strategic Management Journal, 25, 637-653. http://dx.doi.org/10.1002/smj.405

Kahle, L. R., \& Pamela, H. M. (1985). Physical attractiveness of the celebrity endorser: a social adaptation perspective. Journal of Consumer Research, 11(March), 954-961. http://dx.doi.org/10.1086/209029

Kaikati, J. G. (1987). Celebrity Advertising: A Review and Synthesis. International Journal of Advertising, 6(2), 93-106.

Kirmani, A., \& Baba, S. (1998). Effects of source congruity on brand attitudes and beliefs: the moderating role of issue-relevant elaboration. Journal of Consumer Psychology, 7(1), 25-47. http://dx.doi.org/10.1207/s15327663jcp0701_02

Kotler, P. (1999) Marketing para o século XXI: como criar, conquistar e dominar mercados. Tradutor: Cristina Bazán (10th ed.). São Paulo: Futura.

Kotler, P., \& Armstrong, G. (2003). Princípios de Marketing. Tradutor: Arlete Simille Marques (9th ed.). São Paulo: Prentice Hall.

Leschnikowski, K., Schweizer, M., \& Drengner, J. (2006). Celebrities as image conditioner for brands? An empirical study based on the match-up hypothesis. 2006 AMA Winter Educators' Conference. Proceedings, American Marketing Association, 17, Chicago, IL.

Malhotra, N. (2001). Pesquisa de marketing (3rd ed.). Porto Alegre: Bookmam.

Matos, C. A., \& Veiga, R. T. (2002). A influência do conteúdo e da freqüência de notícias relativas às empresas nas atitudes dos consumidores. XXVI ENANPAD, Bahia, 25, 2002, Anais.

Mccarthy, J., \& Perreaut, J. W. (1997). Marketing Essencial: uma abordagem gerencial e global. Tradutor: Ailton Bomfim Brandão. São Paulo: Atlas.

Mccracken, G. (1989). Who is the celebrity endorser? Cultural foundations of the endorsement process. Journal of Consumer Research, 16(3), 310-321. http://dx.doi.org/10.1086/209217

O'mahony, S., \& Tony, M. (1998). The impact of celebrity endorsements on consumers. Irish Marketing Review, $10(2), 15-24$.

Pornpitakpan, C. (2003). Validation of the celebrity endorsers credibility scale: Evidence from Asians. Journal of Marketing Management, 19, 179-195.

Rindova, V., Pollock, T., \& Hayward, M. (2006). Celebrity firms: the social construction of market popularity. Academy of Management Review, 31(1), 50-71. http://dx.doi.org/10.5465/AMR.2006.19379624

Sakellarides, C. (1999). O marketing das celebridades. Executive Digest.

Sengupta, J., Ronald, C. G., \& David, S. B. (1997). All cues are not created equal: obtaining attitude persistence under low-involvement conditions. Journal of Consumer Research, 23(March), 351-361. http://dx.doi.org/10.1086/209488

Silvera, D. H., \& Austad, B. (2004). Factors predicting the effectiveness of celebrity endorsement $\begin{array}{llll}\text { advertisements. } & \text { Journal }\end{array}$ http://dx.doi.org/10.1108/03090560410560218

Teich, D. H. (2008). A publicidade usa cada vez mais celebridades para vender. Ad News, São Paulo, 15, 30-38.

Till, B. D., Sarah, H., \& Randi, P. (2006). Understanding celebrity endorsement: a classical conditioning approach. 2006 AMA Winter Educators' Conference. Proceedings, American Marketing Association, 17, Chicago, IL. 
Tripp, C., \& Thomas, D. J. (1990). The Effect of Multiple Product Endorsements by Celebrities on Consumer Atitudes and Intentions. Journal of Consumer Research, 20(4), 535-547. http://dx.doi.org/10.1086/209368

Walker, M., Langmeyer, L., \& Langmeyer, D. (1992). Celebrity endorsers: Do you get what you pay for? Journal of Services Marketing, 6(4), 35-42. http://dx.doi.org/10.1108/EUM0000000002531

\section{Copyrights}

Copyright for this article is retained by the author(s), with first publication rights granted to the journal.

This is an open-access article distributed under the terms and conditions of the Creative Commons Attribution license (http://creativecommons.org/licenses/by/3.0/). 